\title{
PCAT1 Gene
}

National Cancer Institute

\section{Source}

National Cancer Institute. PCAT1 Gene. NCI Thesaurus. Code C132158.

This gene may be involved in cancer progression. 